\title{
School Mediators in the Romanian Education System. A Discussion on Their Role in Addressing Educational Inequalities
}

\author{
Florina Pop ${ }^{1}$, Bianca Balea $^{1 *}$ \\ ${ }^{1}$ Babeş-Bolyai University Cluj-Napoca, Faculty of Sociology and Social Work, 128-130 21 Decembrie 1989 Blvd., \\ 400604 - Cluj-Napoca, Romania.
}

KEYWORDS

Educational inequalities Roma minority School mediators

\begin{abstract}
Based on findings from the project 'Socio-graphic mapping of the Roma Communities in Romania for a community-level monitoring of changes with regard to Roma integration', the article analyses the role of school mediators in influencing school practices for the reduction of the inequalities Roma students face within the education system. This study investigates the school mediators' perception of causes and solutions for the difficulties Roma students face within the education system, while keeping in mind the current legislation and the public discourse on Roma. In order to gain a comprehensive understanding, we also investigate school mediators' perception towards their work, as well as the manner they evaluate collaboration with colleagues, Roma families and other local stakeholders. Our findings illustrate that the school mediator carries out a multitude of tasks sometimes only partly related to the field of school mediation. At the same time, school mediators engage in a type of public discourse with regard to Roma which highlights individual responsibility and merits as solutions in order to overcome disadvantage. With regard to work satisfaction, although school mediators are poorly trained and they deal with a difficult and high amount of work, they report being highly satisfied with some aspects of their work.
\end{abstract}

\footnotetext{
* Contact address: pop.florina@ymail.com (F. Pop)
} 


\section{Introduction}

\section{Understanding Roma educational attainment}

According to the 2011 Population and Housing Census, 3.2\% of the Romanian population identify as Roma ethnics. Considering that ethnicity is selfdeclared and that $0.3 \%$ of the total population refused to declare their ethnic belonging, it is suggested to interpret these data cautiously (Duminică et al. 2013). Because of the stigma associated with Roma ethnicity, it is possible that some the $0.3 \%$ who did not register their ethnicity are Roma ethnics or that some Roma identified themselves with another ethnic belonging.

In terms of education, across Europe, Roma children have encountered difficulties in access to education, due to a variety of factors, including structurally determined opportunities, as well as locally based interactions or processes influencing Roma access to education. Historically, in Romania, during the communist period, a high proportion of Roma children and youth were enrolled in special schools or, if accepted in the mainstream education system, they were often denied proper education through discriminatory practices within the school context (Center for Documentation and Information on Minorities in Europe - Southeast Europe 2001). Roma children were also discriminated because of their socio-economic status, because of the financial difficulties most Roma families were faced with, as people associated poverty to inferior intellect (Center for Documentation and Information on Minorities in Europe - Southeast Europe 2001). After the fall of the communist regime, in 1989, the educational attainment level of Roma minority ethnics remained low, as did their school-related performance. More than $7 \%$ of Roma over the age of 14 who graduated elementary school were functionally illiterate, $28 \%$ of those who attended elementary school, but did not graduate were functionally illiterate and $88 \%$ of those who did not attend school at all were illiterate (Center for Documentation and Information on Minorities in Europe - Southeast Europe 2001). Moreover, more than 22\% of Roma minority ethnics over 14 years old were illiterate, as compared to $2 \%$ in the case of the non-Roma. More recent data from within the member states of 
the European Union shows that the Roma population registers a much lower educational attendance and achievement level than the non-Roma population. The National Strategic Report Regarding the Social Protection and Inclusion 2008-2010 illustrates the situation of Roma people in Romania during the year 2008 , by showing that only $9 \%$ of the Roma young adults (18-30 years old) are upper secondary education graduates (compared to $41 \%$ of the non- Roma population), $2 \%$ graduated from higher education (compared to $27 \%$ in the case of the non-Roma population) and $28 \%$ are illiterate. Similarly, a survey conducted in 2011 in 11 member states of the European Union (European Union Agency for Fundamental Rights 2014) showed that in Romania 22\% of the Roma school-age children do not attend school, while less than $10 \%$ complete upper secondary education. When compared to other countries, $24 \%$ of Romanian Roma adolescents aged 16 have never attended school, compared to $44 \%$ in Greece, but also to $3 \%$ in Hungary and $1 \%$ in Slovakia.

Although the Romanian legislative framework, while struggling to align to European legislation, has started a reform in what concerns the education system, insufficient progress has been made, due to the lack of clarity within this framework (Vincze and Harbula 2011). In this respect, only a small percentage of Roma graduate higher education, while one of the reasons the number of Roma graduates has increased since 1993 is the existence of reserved places for Roma students in universities (European Commission 2010). Similar results are collected in a study conducted in 2012, which shows that only $17.1 \%$ of Romanian Roma youth are high school or university graduates, compared to $60 \%$ in the non-Roma population. However, some improvements are visible if we compare the percentage of Roma youth who graduated high school in 1989 as compared to 2012, where the percentage has doubled (Duminică et al. 2013).

The participation of Roma children and youth in education is determined by a series of factors, among which we mention school characteristics such as physical distance between the areas where the Roma live and the public schools, overpopulated schools and investments made in schools (Duminică and Preda 2003), Roma families' financial resources, 
teachers' characteristics, their studies and experience (Fleck and Rughiniş 2008). Nevertheless, other reasons are discrimination and segregation in schools or classrooms (Vincze and Hossu 2014). Fleck and Rughiniş (2008) assert that school segregation affects the quality of education and also the experiences of children and is to be considered as one of the important causes of the low educational attainment in the case of Roma ethnics.

\section{Theoretical framework}

\section{A brief history of school mediation in Romania}

The concept of school mediation and the position of school mediator were first introduced in Romania after the year 1990. Romani Criss, a Romafocused non-governmental organisation, in cooperation with the Intercultural Institute, initiated actions towards creating the position of school mediator in the Romanian education system. In 1998 and 1999, school mediators were trained and employed within a pilot project designed to address early school leaving, called the 'Second Chance Program'. The project was started by Open Society Foundation and continued by Education Centre 2000+ (Vincze and Harbula 2011). Their role in working with Roma families and students was to provide support for Roma children and their families in order to improve their educational participation, to link schools to Roma communities, to consult and to provide counselling for Roma community members, to prevent and to mediate conflicts between families and schools, to raise awareness for the problems Roma minority ethnics face and to promote multicultural values in an inclusive educational environment. According to the Strategy for the Inclusion of the Romanian Citizens of Roma Ethnicity for 2015-2020 adopted by the Romanian Government, one of the priorities in fighting school segregation and barriers in education access for the Roma is continuing to implement training programs and to employ school mediators in institutions where Roma children make up more than $15 \%$ of all the children enrolled. As far as results are concerned, in terms of employment, the Romanian 
Government mentions 600 school mediators as an outcome for the year 2016, whereas by the year 2020, 1680 school mediators would be employed.

School mediation is one of the important measures developed to provide support for Roma students. Unfortunately, there is scarce information about the impact of this measure, and the work of school mediators is described within a vague legislative framework. In our paper, we are interested in understanding school mediators' perception about their work, as well as the causes and solutions of the difficulties Roma students face within the education system, as perceived by the mediators. At the same time, we investigate and discuss whether the manner school mediators understand and perform their work provides a comprehensive framework in which they can influence school practices and eventually reduce the inequalities faced by Roma students within the education system.

\section{A framework for studying educational inequalities}

Numerous authors draw attention to the fact that discussions on class distinctions and structural inequality have been largely replaced in the last decades by a discourse highlighting individual responsibility to overcome disadvantage, relying primarily on personal qualities rather than on state intervention (Gillies 2005). Social exclusion theory has added another stigma, by focusing on the qualities the excluded individuals lack in order to become 'responsible risk takers' (Gillies 2005, 837) in a meritocratic society. From this perspective, current debates on inequality have succeeded to shift focus from the structural causes of inequality and the processes that naturalise inequalities to an individualised explanation of inequality and risk (Giddens 1998; Savage 2000). In addition, particular attention is given to translate social rights into a form of individualised citizenship, while equating prosperity with merit and poverty with not taking advantage of state-created opportunities (Gillies 2005; Rose 1999).

Bourdieu's theory has been influential in showing how inequalities are transmitted and eventually explained within an educational system that 
values differently the cultural capital of students in relation to class (1977). With regard to our study, it is important to stress that the Bourdieuian framework views the education system as one of the main channels that enables the social reproduction of inequalities. It is based on the fact that possession of cultural capital and familiarity with the dominant norms within a society allow for upper and middle class students to become successful at school, whereas lower class students are disadvantaged in this competition (Sullivan 2002). From this perspective, differences are generally legitimated by referring to a meritocratic educational system, minimizing the role of social structure in perpetuating class inequalities. Moi (1991) suggests that the major critique of Bourdieu's social theory is that he undertheorized dimensions such as gender and race in favour of class. This point of view is embraced by the great majority of feminist sociologists dealing with the work of Bourdieu (Adkins 2004; Einspahr 2010; Lovell 2000; McLeod 2005; McNay 1999; Skeggs 1997). At the same time, Moi credits Bourdieu for developing a 'microtheory of social power' (Moi 1991, 1019) that allows the researcher to analyse the apparently insignificant details of everyday life in the light of the social power analysis.

Beside the focus on personal responsibility to overcome disadvantage, the meritocracy hypothesis has been employed in multiple ways in order to legitimate differences in educational attainment level. Hurn $(1993,45)$ argues that in a meritocratic society 'ability and effort count for more than privilege and inherited status' and society provides individuals with all needed opportunities for success. According to Kennedy and Power (2010), in a meritocratic society success and failure depend solely on the individuals and their merits in terms of innate talent, hard work and 'being the right kind of (middle class) self' (Gillies 2005, 837). Bowles and Herbert (2002) go further to assert that the education system eventually legitimates inequality by setting the stage so that unequal economic positions are assigned based on a meritocratic system failing to incorporate concepts such as fairness and justice. The same authors argue that educational inequalities are legitimated using two mechanisms: feelings of inevitability with regard to one's position 
and role within the society, and moral desirability, described as 'everyone gets what they deserve' (Bowles and Herbert 2002, 104). In a capitalist society, such hierarchies are put in place by ideologies and policies meant to meet the needs of a neo-liberal welfare agenda. Through this discourse, the state serves the interests of the privileged, while inequalities are reproduced, hardly allowing upwards social mobility.

The investigation of the social reproduction of inequality and difference in education raises numerous questions about the role of the school, particularly teachers, the role of the parents, and not least the role of educational policies. Based on European data comparing the level of educational attainment of students in different countries, Van Zanten (2005) concludes that despite various interventions aimed at reducing differences in education, inequalities continue to be transposed upwards. Furthermore, differences in the level of educational attainment have actually widened, as lower students have become even more disadvantaged in matters of access and results in the education system, while the privileged categories continue to score highest in assessment test. The same author discusses the existence of new and continuously changing contexts where the reproduction of inequalities occurs. For instance, globalisation creates a new market where specific opportunities and constraints are transformed into reproduction strategies which serve the interest of the upper classes. The author argues that lower classes are disadvantaged because they are more likely to be disconnected from globalisation and thus they are provided with fewer opportunities in education and further on in the labour market. Van Zanten (2005) also poignantly discusses the workings of education policies, which sometimes facilitate segregation themselves through incorporating discriminatory forms of student selection and then explaining away ethnic or class-based selection, as well as self-selection, as matters of meritocracy rather than facets of discrimination.

As Gillies (2005) notes, individuals are empowered to become responsible risk takers and to achieve success according to their own "giftedness" (Bourdieu 1977) or otherwise they will exclude themselves from 
society's opportunities. Drawing on the framework introduced by Bourdieu (1977) we will illustrate how educational inequalities are hardly addressed by the educational policy aimed at the Roma. Even more, these educational policies create the stage for the reproduction of various strategies that put the Roma in an inferior position and legitimate differences as being the result of (lack of) individual effort rather than the outcome of structural inequality.

\section{Aim of the study}

Considering the theoretical framework presented above, our research will illustrate the role of school mediators in influencing school practices for the reduction of the inequalities Roma students face within the Romanian education system. We argue that although the school mediators identify a series of structural problems at local level and beyond with regard to the school attendance of Roma children, they eventually internalize a type of common public discourse towards the Roma, which places the responsibility for school integration of Roma children solely on Roma parents/families, leaving aside the structural causes of educational inequalities. This is in part due to them having limited instruments at their disposal, in terms of abilities and role in school decision-making processes as relevant stakeholders.

In order to substantiate this general argument, we address several specific aspects:

O1. Firstly, we offer a general description of the school mediator's condition, taking in consideration their work activities, work experience and several demographic variables.

O2. Secondly, we are interested in the school mediators' perception of causes and solutions for reducing education inequalities. In this regard, we expect that school mediators view Roma families as responsible for not providing their children with the support they need in school.

O3. Finally, our present research focuses on investigating school mediators' satisfaction with their work, having in mind the level of cooperation with teachers and other local and regional resources (e.g. county 
school inspectorates), and also the legislative and administrative difficulties of bringing this profession under regulation.

\section{Sample and method}

The present analysis relies on the database of the Socio-graphic mapping of the Roma Communities in Romania project. The aim of the project was to elaborate sociological descriptions of 50 localities with more than 30.000 inhabitants and 25 community studies. In order to meet the project's objective, specific and relevant research tools were developed. Besides the data regarding the social and economic situation of Roma population at the local level, the project also collected quantitative data regarding the situation of social workers, health mediators and school mediators in the Roma communities. Along these lines, one of the project's secondary objectives was to offer an in-depth understanding of school mediators' condition in Romania. A mail survey was conducted at the end of 2015 and the beginning of 2016. The population interviewed consisted of 489 school mediators and Romani language teachers from all over the country. They were contacted with the help of the regional school inspectors on Roma issues. Although respondents were allowed a reasonable amount of time (one month) to fill out the questionnaire, the response rate was moderate - very common for this type of survey -, about $47 \%$, out of which 171 were school mediators. The topics covered in the questionnaire include different aspects about children from the Roma communities in the localities where they work (e.g. number of children attending preschool and school, number of dropouts, information about the main school problems they encounter, etc.), the role of the school mediator in the educational system (e.g. how they perceive their work, problems and solutions they identify with regards to Roma children school drop-outs) and different aspects of their work (e.g. activities, institutional relations, work satisfaction). Nonetheless, some socio-demographic variables were also measured in the questionnaire, among them age, gender, education. 
For the purpose of this study, several statistical analyses were conducted using SPSS. In order to map a general description of the school mediator's condition we used descriptive statistics. Furthermore, we tested the significance of the relationships between different variables using the chisquare test of independence and we analysed contingency tables in order to describe how variables introduced in the model relate to each other. The way in which variables used in the analyses were measured within the questionnaire will be presented in the next section.

\section{Analysis and results}

\section{O1. A description of school mediators ${ }^{1}$ and their activities}

Almost $50 \%$ of the school mediators in our sample were employed in 2007 or 2008, whereas 20\% started their job in 2013, 2014 and 2015. For the majority of them this is a full-time job. However, $14 \%$ report performing other duties as well within their schools besides their job of school mediators (e.g. most frequently substitute teacher, driver, librarian, teacher for various subjects such as Romani language, cleaning personnel, psychopedagogist). In addition, $68 \%$ of school mediators report working in one school unit, while only a small proportion report working in three or four school units. In average a school mediator is 42 years old, female (59\%) and a Roma ethnic $(68 \%)$. With regard to Romani language, $45 \%$ of school mediators state they have a good knowledge of the Romani language, while at the other end 11\%

\footnotetext{
1 According to Order no. 1539 from 19/07/2007 and Notification no. 25.436 from 28/01/2008, both issued by the Ministry of Education, Research and Youth, school mediators are graduates of mandatory education or high school studies and qualified as school mediators in formally recognized training programs. It is recommended that school mediators are members of local disadvantaged communities, with a good knowledge of the local language and culture. The responsibilities of the school mediators are to facilitate the communication between families and schools, to monitor educational participation and encourage preschool and school age children to participate in school, to promote desegregation, as well as the organizations of remedial and other educational support programs (e.g. after school programs), to collect and report statistics with regard to school participation, at risk children and youth, school abandonment, to raise awareness towards intercultural tolerance and to promote multicultural values in an inclusive educational environment.
} 
state they have just started learning the language. The rest of them declare they have no knowledge of the Romani language and at the same time they do not consider this as being important for their work. Almost all of them are qualified as school mediators. The majority of them were qualified and employed as school mediators seven years ago, with no further participation in other training or qualification programs in the following years. In terms of education, it is very common for them to have graduated from high school, while only 2 in 10 school mediators have a tertiary education. However, there are a few school mediators who have graduated only eight grades or a vocational school (14\%). In what concerns being employed elsewhere or performing other activities outside school, $16 \%$ report having another full time or part time job (teacher, priest, preschool teacher, managing their own business, conducting traditional activities such as weaving twigs or performing seasonal informal activities).

The majority of school mediators report that their main work activity is to monitor the participation of Roma children in school. Only a small proportion report conducting activities in the field of raising awareness and developing interventions with regard to the situation of children who have never been enrolled in school or promoting ethnic and cultural diversity through specific programs. This is an important finding, given that the current legislation describing the responsibilities of school mediators' states that they are involved in promoting multicultural values so as to create an (ethnically) inclusive educational environment. Furthermore, when asked whether they organise or take part in organising support programs for improving the academic performance in the case of Roma children, it appears only a small share of school mediators are engaged in such activities. In fact, these types of activities are listed as the most infrequent, surpassed by a wide range of activities such as collecting data on several domains related to school participation of Roma children, but also organising extracurricular activities. Our findings illustrate that a great part of the activities developed by the school mediators are in the field of data collection and monitoring, but it is 
also important to highlight that the activities they report as performing most frequently are home visits in the Roma settlements assigned to their schools.

Table 1. Frequency of work activities. Mean values ( 5 categories in total, $5=$ weekly; $3=$ semestrial; $1=$ Never )

\begin{tabular}{|l|l|l|}
\hline & Mean & $\begin{array}{l}\text { Std. } \\
\text { Dev. }\end{array}$ \\
\hline $\begin{array}{l}\text { Home visits in the Roma community assigned to their school } \\
\text { Monitoring the school and extracurricular situation of children at risk } \\
\text { of dropping out }\end{array}$ & 4.23 & 0.56 \\
\hline $\begin{array}{l}\text { Monitoring and encouraging Roma students to attend classes within } \\
\text { alternative/ supplementary support programs }\end{array}$ & 4.16 & 1.22 \\
\hline $\begin{array}{l}\text { Updating data on Roma children at risk of dropping out of school } \\
\text { Collection of relevant statistical data to monitor access to education } \\
\text { and keeping children in the compulsory education (10 years/grades) }\end{array}$ & 3.46 & 1.18 \\
\hline $\begin{array}{l}\text { Organizing extracurricular activities } \\
\text { Monitoring preschool and school age Roma children who were never } \\
\text { enrolled in school }\end{array}$ & 3.17 & 1.16 \\
\hline $\begin{array}{l}\text { Promoting ethno-cultural characteristics in the school environment } \\
\text { involving organizing activities with parents and/or community } \\
\text { members }\end{array}$ & 3.09 & 1.08 \\
\hline $\begin{array}{l}\text { Supporting Roma families in the legal steps required to enrol } \\
\text { children in pre-school / school }\end{array}$ & 3.03 & 1.16 \\
\hline $\begin{array}{l}\text { Proposing solutions for the enrolment of Roma children who have } \\
\text { never been to school }\end{array}$ & 3 & 1.16 \\
\hline $\begin{array}{l}\text { Organizing support programs for improving school performance in } \\
\text { the case of Roma students }\end{array}$ & 2.6 & 1.52 \\
\hline
\end{tabular}


Since more often than not their job descriptions comprise rather general activities related to their work, the list with the activities measured in the questionnaire is not exhaustive. Therefore, school mediators were requested to detail other activities they take upon themselves besides the one mentioned in the above table in an open-ended question section. An interesting finding is that one of the school mediators identified all the above activities in his job description. Other activities mentioned by them were: helping children in doing their homework; collaboration with institutions and NGOs; discussions with Roma leaders; interactive meetings with teachers; daily monitoring of Roma students participation in school; organizing meetings with Roma parents; offering support in obtaining identity documents; visits in the community whenever needed. These answers, along with the hierarchy of activities as seen in the table above, offer a profound understanding regarding school mediators' perception of their own role in the school and in the community. They describe themselves conducting a various range of activities, while their role is hardly defined besides that of data collection and monitoring, the later turning into deliverables the school mediators need to submit periodically. It might be that school mediators perform such diverse activities because it is generally left to the decision local of authorities and particularly schools to organise the work of the school mediators in the field of interventions and to some extent to find the financial resources to develop such interventions.

\section{O2. School mediators' perception of the causes of education inequalities and solutions for reducing these}

Poverty, understood as lack of material and financial resources, is identified by $85 \%$ of our respondents as the main cause for school absenteeism in the case of Roma children. This finding is in line with studies (National Institute of Statistics 2011, 2012a, 2012b) illustrating that a great share of Romanian Roma minority ethnics lives in poverty and this is affecting their participation in education. However, a different and to a certain extent unexpected approach from the part of the school mediators is identified when they are 
asked what they view as solutions in order to prevent school absenteeism in the case of Roma children. The first solutions they suggest are maintaining the school-family relationship and monitoring children's participation in school, followed by advising disadvantaged families on the role and importance of education. Only a small number identify measures such as providing material and financial aid to Roma families and children among the most adequate solutions.

We argue that we can make sense of these findings using two directions. First, the public discourse on Roma is so much centred on the lack of education and on poverty as a result of not pursuing the opportunity for education that it has become almost impossible to dissociate Roma ethnicity from poverty, in the sense of poverty created by not participating in education and further on the labour market (Pop 2012). In addition, the legislative framework stressing the importance of social inclusion builds on the same arguments, of providing opportunities which the excluded should use, while very little attention is given to structural inequalities which create and perpetuate unequal access to these opportunities. From our findings, such opportunities are counselling the family so they understand the importance of education and bringing parents closer to schools. Although this might improve Roma children's educational attainment and it cannot be contested as a necessary activity in the work of a school mediator, our question is whether these types of activities alone have the power to influence upward mobility and eventually replace structural forms of advantage in the field of education. Yet, the school mediator operates within a public and legislative discourse towards the Roma which acknowledges the existence of disadvantage in the form of poverty and exclusion, but the interventions they are expected to perform aim at empowering the excluded individuals to address these problems as a form of personal responsibility within the society.

Another manner of approaching these results is by referring to what school mediators view as achievable through their work. While eradicating poverty remains far from reach, the duties of their everyday activities are tangible and measurable, therefore they pinpoint to what is within their 
control, particularly maintaining cooperation with Roma families. The question that arises from here is to what extent school mediators are viewed and view themselves as important stakeholders in local decision making processes and can actually influence the distribution of local resources. If we look at our findings, school mediators rank working together with local authorities third in terms of important solutions for preventing school absenteeism in the case of Roma children, after the range of family-addressed counselling and monitoring activities.

Table 2: Causes for school absenteeism (most important)

\begin{tabular}{|l|r|r|r|}
\hline & $\begin{array}{l}\text { First } \\
\text { choice\% }\end{array}$ & \multicolumn{1}{|l|}{$\begin{array}{l}\text { Second } \\
\text { choice\% }\end{array}$} & $\begin{array}{l}\text { Third } \\
\text { choice\% }\end{array}$ \\
\hline Distance from school & 6 & 6 & 10 \\
\hline $\begin{array}{l}\text { Poverty (lack of material and financial } \\
\text { resources) }\end{array}$ & 85 & 14 & 2 \\
\hline $\begin{array}{l}\text { Seasonal work (especially during } \\
\text { autumn) }\end{array}$ & 6 & 63 & 23 \\
\hline Conflictual family environment & 3 & 16 & 57 \\
\hline Conflictual school environment & 0 & 1,5 & 7,9 \\
\hline
\end{tabular}

Other causes of school absenteeism in the case of Roma children mentioned by school mediators within an open-ended question section are: parents' lack of education (mentioned several times); early marriage (mentioned several times); medical reasons; alcohol consumption; parents' lack of interest toward school (mentioned several times); migration; monoparental families; parents not responsible with regard to education; low confidence in education; lack of educational culture; parents' absence from home; parents' mentality; parents working abroad (mentioned several times); children left in the care of grandparents; segregation; traditions and customs. 
Table 3: Solutions against school dropout (most important)

\begin{tabular}{|c|c|c|c|}
\hline & $\begin{array}{l}\text { First } \\
\text { choice } \%\end{array}$ & $\begin{array}{l}\text { Second } \\
\text { choice } \%\end{array}$ & $\begin{array}{l}\text { Third } \\
\text { choice \% }\end{array}$ \\
\hline Maintaining the family-school relation & 58 & 15 & 7 \\
\hline Monitoring children's school attendance & 10 & 36 & 9 \\
\hline $\begin{array}{l}\text { Maintaining the relation with local } \\
\text { authorities }\end{array}$ & 3 & 6 & 15 \\
\hline Free transportation and meals & 8 & 6 & 8 \\
\hline Providing school supplies and clothing & 7 & 11 & 14 \\
\hline $\begin{array}{l}\text { Free public transportation during the } \\
\text { school year }\end{array}$ & 0 & 1 & 2 \\
\hline $\begin{array}{l}\text { Prevention of deviant behaviour: violence, } \\
\text { drinking alcohol, prostitution }\end{array}$ & 1 & 3 & 3 \\
\hline $\begin{array}{l}\text { Advising disadvantaged families on the } \\
\text { role and importance of education }\end{array}$ & 10 & 19 & 24 \\
\hline $\begin{array}{l}\text { Advising students on the importance of } \\
\text { graduating school }\end{array}$ & 3 & 3 & 18 \\
\hline
\end{tabular}

After poverty, seasonal work and a conflictual family environment are listed second, respectively third important causes for absenteeism with regard to Roma children. Along the same lines, although acknowledging students doing seasonal work, this is hardly addressed in terms of finding solutions such as providing families with a sufficient minimum income.

On the contrary, when asked what other solutions they identify for preventing school abandonment, mediators indicate coercive methods as most important, in this case making the payment of state child allowances dependent on the children's attendance in school. Once again, these recommendations are common in the public discourse as well, illustrating how inequality pretends to be meritocracy, which questions the very essence of the welfare state, more precisely the principle of universalism in providing 
citizens their social rights. Roma minority ethnics are expected to participate in education so as to create for themselves the means to change their disadvantageous position, by simply taking advantage of this opportunity offered by the state. This discourse is yet another channel of perpetuating inequalities, by blaming the impoverished Roma for their inferior social status, which puts them in a disadvantaged position and blocks their access to state-created opportunities. In addition, misconstruing child allowance as a state mechanism of investing in children's education that is wasted on the Roma might conceivably be understood as yet another way of blaming the undeserving Roma for misspending a significant chunk of the national budget (Vincze and Hossu 2014).

Another solution identified by school mediators is providing jobs for students so that they have the necessary financial resources to attend school. These findings stress that although labour at young ages is viewed as socially unacceptable, when it comes to Roma children it is not only acceptable, but viewed as a solution to overcome poverty, thus replacing state responsibility to provide universal access to education, independent of the social position of the individual. In addition, school mediators report that (informal) seasonal work is one of the causes of school absenteeism in the case of Roma children, but since students have no alternative for financial and material support, they recommend Roma adolescents to formally join the labour market. As illustrated in other studies (Pop and Roth 2015), Roma minority ethnics are expected to work harder so they become the 'right kind of Roma', which can overcome disadvantage and can legitimate their merits and at the same time can perform as successful individuals within the society. As Gillies (2005) explains, this has become an important issue on the neo-liberal agenda, where hierarchies and inequalities are naturalised as deservedness rather than addressed in a social welfare approach that relies on the ideas of fairness and justice. 
Table 4: Most important local and structural problems of Roma children (4 categories in total, $4=$ a very important problem; $1=$ not a problem at all)

\begin{tabular}{|l|c|}
\hline & Mean \\
\hline $\begin{array}{l}\text { Roma children drop out of school because of the lack of material and } \\
\text { financial resources }\end{array}$ & 2.92 \\
\hline Roma parents are not interested in keeping their children in school & 2.53 \\
\hline $\begin{array}{l}\text { Roma children drop out of school because, occasionally, they migrate to } \\
\text { work abroad with their parents }\end{array}$ & 2.31 \\
\hline Roma children drop out of school because they are involved in labour & 2.25 \\
\hline Roma children drop out of school due to medical reasons & 1.94 \\
\hline In general, Roma children live far from school & 1.75 \\
\hline $\begin{array}{l}\text { Non-Roma children's parents do not agree that their children study in the } \\
\text { same school with the Roma children }\end{array}$ & 1.56 \\
\hline $\begin{array}{l}\text { There were situations at school when Roma children bullied the non-Roma } \\
\text { children }\end{array}$ & 1.45 \\
\hline $\begin{array}{l}\text { There were situations at school where Roma children were humiliated by } \\
\text { non-Roma children because of their ethnicity }\end{array}$ & 1.33 \\
\hline Teachers do not like working with Roma children & 1.32 \\
\hline $\begin{array}{l}\text { Roma children have difficulties in understanding the language spoken at } \\
\text { school }\end{array}$ & 1.31 \\
\hline \begin{tabular}{l} 
There were situations at school when Roma children were humiliated by \\
\hline
\end{tabular} & 1.19 \\
\hline
\end{tabular}

* score over 2 - it is a problem; between 1 and 2, most probably a problem; 1 it is not considered a problem

It is interesting to see that although segregation is listed as an important structural cause of early school leaving, school mediators hardly identify interventions in this direction as necessary. To the other end of the spectrum, only a small share of school mediators consider that financial aid should be provided to Roma families, so that they reach a level of minimum income 
according to their needs. Similar to our previous findings, they rank greater family involvement in education and even preventing addictions higher in terms of required solutions than any other type of income related state support measure.

This table reveals a very intriguing finding. More often than not, school mediators do not consider a problem the fact that Roma children live far from school. However, 30 per cent of them report that Roma children have to come to school from a distance of more than 3 kilometres. Similarly, 42 school mediators out of 170 are assigned to a Roma community located more than 5 kilometres away from school. Even when controlling for distance from the school (greater than $3 \mathrm{~km}$ ), $61 \%$ of school mediators do not see the distance as a problem for Roma children`s participation in school.

Another interesting finding retrieved from the above table is that two opposed problems are listed as almost equally important in terms of causes for school absenteeism in the case of Roma children, illustrating the clashes between discourse and actual problems discussed earlier. Furthermore, a cross tabulation analysis between these two variables shows a significant association, $\mathrm{X}^{2}(9, \mathrm{~N}=159)=39.47, \mathrm{p}=.00$. There is a chance of $44 \%$ for a school mediator to claim that both lack of resources and parents' interest in school are very important problems for Roma children. The Gama coefficient $=.32$ also showed a moderate positive association between these variables, significant at $\mathrm{p}=.00$.

As already discussed when analysing the legislative context in the field of school mediation, the work of school mediators has been vaguely and inconsistently defined and implemented. This inconsistency is to be found in the work of school mediators as well, who perhaps see themselves left to deal with a wide range of local problems, while having no instruments and power within a local structure created to maintain the status quo of the privileged and 'meritorious' students.

However, it is equally important to stress that within our research school mediators have not mentioned any type of discriminatory practices or processes of inferiorization experienced by Roma students in schools. These 
findings contradict other studies highlighting that ethnic divisions in the school setting and discrimination are actually important aspects in Roma students and families' disengagement with school (Szalai, Messing and Nemenyi 2010; Szalai 2011; Vincze and Hossu 2014; Pop and Roth 2015).

While one cannot assert that these two assumptions can coexist, these findings highlight that poverty remains central but it becomes more and more defined as personal responsibility as we get close to reproducing aspects of the public discourse and also to designing interventions. Following the idea of personal responsibility, the expectation is that a lower social status can be overcome by hard work and deservedness and the reproduction of social status occurs within an approach which blames the poor for being poor and thus reduces state's responsibility.

\section{O3. Work satisfaction and collaboration with stakeholders and the Roma community}

School mediators generally report high levels of work satisfaction, good relations with other school employees and contentment regarding their work experience. At the same time, they are more likely to be dissatisfied with their salary, work volume and career prospects. In order to comprehend these results, we have to keep in mind that for many years the profession of school mediator was not regulated and their duties and tasks are still unclear. Furthermore, as seen above, the data shows that some school mediators perform other activities as well, and some of them are hardly related with their job description.

When it comes to their perception regarding the way they collaborate with different stakeholders, school mediators report a very good relation with the school directors $(82 \%)$, teachers and preschool teachers $(75 \%)$, results that could suggest that most of the school mediators conduct their activities in a pleasant and supportive working environment. On the contrary, school mediators report low levels of satisfaction (just $15 \%$ are very satisfied) regarding their collaboration with Roma regional experts (e.g. representative of Social Work institutions and Child protection, representative of Regional 
office of the National Agency for Roma) and moderate satisfaction (35\% are very satisfied) concerning their relation with local experts (e.g. social worker, local Roma expert, representative of County Office for Roma). It is important to stress that, when asked about their collaboration with Roma communities to which they are assigned, almost all of school mediators (97\%) mentioned a good or very good relation.

Table 6: How satisfied are you with...? (1- not at all; 5 very satisfied)

\begin{tabular}{|l|c|}
\hline & Mean \\
\hline Your work & 4.3 \\
\hline Relation with other school employees & 4.7 \\
\hline Work experience & 4.5 \\
\hline Relation with family doctor & 4.4 \\
\hline Relation with Roma community assigned to their school & 4.4 \\
\hline Work program & 4.3 \\
\hline Work contract & 4.2 \\
\hline Work volume & 3.9 \\
\hline Career prospects & 3.4 \\
\hline Salary & 2.4 \\
\hline
\end{tabular}

In the context of these results, it is crucial to acknowledge some characteristics of the survey that might have had an impact on the school mediators' answers to the questionnaire. As already stated above (see Sample and Method section) the data on which we report was collected through a mail survey. The school mediators' contact details were obtained via the regional school inspectors on Roma issues. Moreover, there were situations when school mediators received the questionnaire from the county school inspector or the school principal. Our understanding was that some school mediators 
viewed this task (filling in the questionnaire) as a work task and, therefore, their answers might have been biased. Therefore, the results regarding their job satisfaction and their opinion about the collaboration with some stakeholders must be looked at through critical lenses, taking into account the issue of social desirability.

\section{Discussion}

Our analysis shows that the work of school mediators is hardly regulated by articulated and coherent measures, starting with the legislative framework. The school mediators trained and employed within the pilot project implemented in 1998 and 1999 found their jobs, after the closure of the program, at the discretion of schools and County Inspectorates, given the legislative gaps and the scarcity of funds allocated to incorporate school mediators as school personnel. Under these circumstances, school mediators performed their work as auxiliary personnel, facing scant job security and a multitude of tasks. Their responsibilities remained unclearly defined within a national context discussing the social inclusion of the Roma as a priority, yet expected to be achieved rather by individual responsibility than through integrated actions to address the structural causes of Roma marginalisation and exclusion.

Based on our data, we can see that the school mediator is often overburdened with a variety of tasks, since they are often employed to perform more than the role of a school mediator (e.g. Romani language teacher, but also other administrative roles). Qualification as a school mediator is mostly the result of short term training within different projects, without a unitary designed training frame. The school mediators are often isolated in terms of the resources they can mobilize, and although they are able to identify the problems that need to be addressed, they can hardly engage in interventions. As a result, the school mediator assumes a type of public discourse with regard to Roma which highlights individual responsibility and merit as solutions to overcoming disadvantage. What is 
striking in terms of findings and raises questions with regard to the school mediator's role in the school setting is that they hardly focus on poverty, informal labour, segregation or inferiorization and discrimination in schools as important aspects to be addressed through state designed interventions. In contrast, the school mediators continue to identify as solutions actions which have proved their limits in preventing early school leaving, but which are actually within their control, as opposed to influencing local policies and allocation of funds, which might be out of their control. In other words, providing counselling and support to poor Roma families in order to understand the importance of education might improve school attainment to some extent, but it can hardly replace structural forms of privilege.

With regard to work satisfaction, school mediators are poorly trained and they deal with a difficult and high amount of work, but they report being highly satisfied with some aspects of their work. They are particularly satisfied with the relations with their colleagues in school, as well as with the relation with the Roma families assigned to their school. This might influence their own perception of the role they have within the education system, making them believe they are expected to build good relations and to prevent conflicts more than to become critically involved in questioning the failures of the already developed interventions. An interested finding is that although they report satisfaction with their work, an important share of the school mediators state they are searching for other type of employment $(15 \%)$, or are currently performing other type of jobs.

\section{Concluding remarks}

Based on our theoretical framework, we have identified several routes through which the social exclusion approach has found its way into the school mediators' perception of the difficulties Roma minority ethnics face in increasing their educational attainment level. For example, pathologizing the Roma as taking part in various addictive behaviours (gambling, alcohol consumption, prostitution) is easier to translate into proposals for 
interventions than to actually pinpoint the fact that child labour or not having the necessary minimum resources is within the state's responsibility to be addressed as social protection measures. In the light of our Bourdieuian framework, some solutions proposed by school mediators (e.g. making child allowances conditional on school attendance) to encourage and support Roma children's participation in education can be seen as a form of gatekeeping, since according to recent studies (Vincze and Hossu 2014; Vincze and Pop 2016) these measures are another manner of blaming the Roma ethnics for being poor and keeping them in an inferior position. Furthermore, instead of using education as a channel for upward mobility, these coercive measures transform education in a tool used by the privileged to maintain or even exacerbate the inequalities among the already disadvantaged, in our case Roma children.

Our recommendations are first in the field of legislation and implementation of the legislation describing the work of the school mediators. It is important to stress that creating the necessary professional setting for the school mediators to conduct their work is one of the first aspects to be clarified before formulating any other expectations regarding this work. In addition, at a macro level, the social inclusion approach to the Roma has long proven its limits and the focus should switch to identifying the structural roots and causes of ethnic inequalities, which should further inform policy measures, as well as individual and family-based interventions. Second, in terms of research, we consider that qualitative research is needed so as to understand the position of the school mediator in schools and in localities, as well as their work with Roma families and students. From a qualitative stance, our interest would be to describe the process through which the school mediator becomes assimilated or not in a context that is supportive towards the Roma. In this respect, are they accepted as relevant stakeholders? Where do they place themselves and where are they placed on the presumed 'us' and 'them' binary divide? How do all these aspects impact their work? Finally, as Moi (1991) puts it, the distribution and processes of social power can explain 
how inequalities can be reproduced through strategies which fit and reproduce the already existing social structures and barriers.

\section{Acknowledgements}

This article is based on the data collected within the project Socio-graphic mapping of the Roma Communities in Romania for a community-level monitoring of changes with regard to Roma integration (SocioRoMap, financed by the Norwegian Financial Mechanism 2009-2014 in the framework of 'Poverty Alleviation in Romania' (RO25).

\section{References}

Adkins, Lisa. 2004. "Introduction: Feminism, Bourdieu and after." The Sociological Review 52(s2): 1-18. doi:10.1111/j.1467-954X.2005.00521.x

Bourdieu, Pierre. 1977. Outline of a Theory of Practice. Cambridge: Cambridge University Press.

Bowles, Samuel, and Herbert Gintis. 2002. "Schooling in capitalist America revisited." Sociology of education 75(1): 1-18.

Center for Documentation and Information on Minorities in Europe-Southeast Europe. 2001. Minorities in Southeast Europe. Roma of Romania. Retrieved March 18, 2012 from: http://www.edrc.ro/resurse/ rapoarte/Roma_of_Romania.pdf.

Duminică, Gelu, Ana Ivasiuc, Sorin Cace, Roxana Toader, and Ana Vizireanu. 2013. Romii din România. De la țap ispăşitor la motor de dezvoltare. Agenția Impreună.

Duminică, Gelu, and Marian Preda. 2003. Accesul romilor pe piața muncii. București: ECA- Editura Cărtii de Agribusiness.

Einspahr, Jennifer. 2010. "Structural domination and structural freedom: A feminist perspective." Feminist Review 94(1): 1-19.

European Union Agency for Fundamental Rights. 2014. Education: the situation of Roma in 11 EU Member States. doi:10.2811/53012

European Commission, Directorate General for Employment, Social Affairs and Equal Opportunities, Unit G4. 2010. Improving the Tools for the Social Inclusion and Non-discrimination of Roma in the EU. Luxembourg: Publications Office of the European Union. 
Fleck, Gabor, and Cosima Rughiniș, eds. 2008. Inclusion and Exclusion of Roma in Present Day Romanian Society. National Agency for Roma. Bucharest: Human Dynamics.

Giddens, Anthony. 1998. The Third Way: The Renewal of Social Democracy. Cambridge: Polity Press.

Gillies, Val. 2005. "Raising the 'Meritocracy' Parenting and the Individualization of Social Class." Journal of Sociology 39(5): 835-853. DOI: $10.1177 / 0038038505058368$

Hurn, Christopher. 1993. The limits and possibilities of schooling. Boston: Allyn \& Bacon.

Kennedy, Margaret, and Martin Power. 2010. "'The smokescreen of meritocracy': Elite education in Ireland and the reproduction of class privilege." Journal for Critical Education Policy Studies 8(2): 222-248.

Lovell, Terry. 2000. "Thinking Feminism With and Against Bourdieu." Feminist Theory 1(1): 11-32.

McLeod, Julie. 2005. "Feminists re-reading Bourdieu: Old debates and new questions about gender habitus and gender change." Theory and Research in Education 3(1): 11-30.

McNay, Lois. 1999. "Gender, Habitus and the Field: Pierre Bourdieu and the Limits of Reflexivity." Theory, Culture and Society 16(1): 95- 117.

Moi, Toril. 1991. "Appropriating Bourdieu: Feminist Theory and Pierre Bourdieu. Sociology of Culture." New Literary History 22(4): 1017-1049.

National Institute of Statistics. 2011. Romania in Figures. Bucharest: General Department of IT and Statistical Infrastructure. Department of Statistical Publications Editing.

National Institute of Statistics, Central Commission for Population and Households' Census 2011 .2012a. Population and Households' Census, 20- 31 October, 2011. Retrieved June 6, 2012 from:

http:/ / www.recensamantromania.ro/wp-content/uploads/2012/02/ Comunicat_DATE_PROVIZORII_RPL_2011.pdf.

National Institute of Statistics, Central Commission for Population and Households' Census 2011. 2012b. Occupied and Unemployed in the $1^{\text {st }}$ trimester of 2012. Retrieved July 2, 2012 from: http://www.insse. ro/cms/files\%5Cstatistici \%5Ccomunicate $\% 5$ Csomaj\%5Csomaj_Ir_12. pdf.

Notification no. 25.436 from 28/01/2008 of Ministry of Education, Research and Youth regarding the activity of school mediators

Order no. 1539 /2007 regarding the employment and activity conditions of the school mediator, published in the Official Gazette of Romania, No. $670 / 1.10 .2007$ 
Pop, Florina, and Maria Roth. 2015. "Ethnic divisions and social capital described in the narratives of young Romanian roma." Copiii de azi sunt părinții de mâine 40: 98-111.

Pop, Florina. 2012. "Education, Occupational Aspirations and Labour Market Entrance in the case of Roma Youth in Romania." Phd diss., BabeșBolyai University of Cluj-Napoca.

Rose, Nikolas. 1999. Powers of Freedom: Reframing Political Thought. Cambridge: Cambridge University Press.

Savage, Mike. 2000. Class Analysis and Social Transformation. Buckingham: Open University Press.

Sullivan, Alice. 2002. "Bourdieu and education: How useful is Bourdieu's theory for researchers?" Netherlands Journal of Social Sciences 38(2): 144166.

Skeggs, Beverley. 1997. Formations of Class and Gender. London: Sage.

Szalai, Julia, Vera Messing, and Maria Nemenyi. 2010. Ethnic and Social Differences in Education in a Comparative Perspective. Budapest: Central European University, Center for Policy Studies.

Szalai, Julia, ed. 2011. Contested Issues of Social Inclusion through Education in Multiethnic Communities across Europe. Budapest: CPS CEU.

Van Zanten, Agnes. 2005. "New modes of reproducing social inequality in education: The changing role of parents, teachers, schools and educational policies." European Educational Research Journal 4(3): 155169.

Vincze, Eniko and Hajnalka Harbula. 2011. Strategii identitare şi educație şcolară: raport de cercetare despre accesul copiilor romi la şcoală (EDUMIGROM/România). Cluj: Editura Fundației pentru Studii Europene.

Vincze, Eniko, and Florina Pop. 2016. “Roma Settlement Formation in a Small Romanian Town - Instances of Ghettoization and Reduction to Bare Life." Intersections. EEJSP 2(1): 183-198. DOI: 10.17356/ieejsp.v2i1.91

Vincze, Eniko, and Elena Hossu, eds. 2014. Marginalizarea socio-teritorială a comunităților de romi din România. Studii de caz în județele Alba, Arad, Călărași, Dolj și Iași. EFES.

Government Decision HG No. 430/ 2001 On Improving the Situation of Roma, published in the Official Gazette of Romania, No. 430 On 25.04.2001.

Government Decision HG No. 430/ 2001 On Improving the Situation of Roma, published in the Official Gazette of Romania, No. 430 On 25.04.2001. 
F. Pop and B. Balea - School Mediators in the Romanian Education System. A Discussion on...

Strategy of the Government of Romania for the Inclusion of the Romanian Citizens Belonging to Roma Minority 2012-2020 for the Period. Retrieved June 2, 2012 from: http:/ / ec.europa.eu/justice/ discrimination/files/Roma_Romania_strategy_en.pdf.

The National Strategic Report regarding the Social protection and inclusion 2008- 2010. Retrieved March 15, 2012 from: http://www.mmuncii. ro/pub/imagemanager/images/file/Rapoarte-Studii/081208Report 2008-2010.pdf. 